\title{
Evaluation of Antibacterial Efficacy of Vitex negundo Linn. extract as Root Canal Irrigant against Enterococcus faecalis and its penetration into Root Dentin: An in-vitro study
}

\author{
Research Article
}

\section{Suruchi Santosh Gupta1 ${ }^{*}$, Nilima Thosar², Nilesh Rathi ${ }^{3}$, Sudhindra M Baliga ${ }^{4}$, Yagnesh Thakkar ${ }^{5}$, Pranjali Deulkar6}

\author{
1. Post Graduate scholar, 2. Professor and Head, 3. Associate Professor, 4. Professor, 6. Post Graduate Scholar \\ Department of Pedodontics and Preventive Dentistry, Sharad Pawar Dental College, Sawangi (Meghe), \\ Wardha-442004, Datta Meghe Institute of Medical Sciences (Deemed to be University), Maharashtra, India \\ 4. Dean, Sharad Pawar Dental College, Sawangi (Meghe), Wardha \\ 5. Clinical Microbiologist at Vishakha Clinical Microbiology Laboratory, Nagpur
}

\begin{abstract}
Introduction: The aim of this study was to evaluate the antibacterial efficacy of Vitex negundo Linn. extract as root canal irrigant against Enterococcus faecalis and its penetration into root dentin. Methods and Materials: Forty single rooted premolars were randomly divided into 4 groups: $3 \%$ Sodium hypochlorite $(\mathrm{NaOCl}), 2 \%$ Chlorhexidine $(\mathrm{CHX}), 100 \mathrm{mg} / \mathrm{ml}$ Vitex negundo Linn. and saline as control all mixed with Rhodamine B dye. Test samples were analysed for bacterial count before and after irrigation using absorbent paper points and the colony forming units were recorded and measured. Sectioning of the samples was performed at three levels $3 \mathrm{~mm}, 6 \mathrm{~mm}, 9 \mathrm{~mm}$ from apex and then these samples were analysed using confocal laser scanning microscopy for penetration depth of the irrigant within the dentinal tubules. Paired t-test and ANOVA test were used to perform statistical analysis with level of significance set at 0.05 Results: The mean CFU/ml count of Enterococcus facealis reduced significantly in all the groups post irrigation. All the irrigants showed maximum penetration depth at coronal third level compared to middle and apical third level respectively. The penetration depth of $\mathrm{NaOCl}$ group was better when compared to CHX group and Vitex negundo Linn. group but the difference was statistically not significant. Conclusion: Although 3\% NaOCl was the most effective irrigant, all agents exerted acceptable antimicrobial activity against Enterococcus faecalis and penetration depth within tubules of dentin.
\end{abstract}

Key Words: Root canal irrigation, Vitex negundo, Enterococcus faecalis, Confocal laser scanning microscope, Herbal irrigants.

\section{Introduction}

Several types of endodontic chemical irrigating solutions have been used for disinfection of root canals. The important properties of root canal irrigants are maximum antibacterial action and pulp tissue dissolving properties with minimal tissue toxicity.(1) Most frequently used intracanal irrigant is sodium hypochlorite because of its high tissue dissolving property. Various concentrations of Sodium hypochlorite $(\mathrm{NaOCl})$ have been used in dentistry but the most effective concentration recommended is $5.25 \%$. Sodium hypochlorite at $2.5 \%-3 \%$ is still the most regularly used concentration of sodium

\section{* Corresponding Author:}

\section{Suruchi Santosh Gupta}

Post Graduate Scholar, Department of Pedodontics and Preventive Dentistry, Sharad Pawar Dental College,

Sawangi (Meghe), Wardha-442004,

Datta Meghe Institute of Medical Sciences (Deemed to be University), Maharashtra, India

Email Id: drsuruchi.19@gmail.com hypochlorite because it causes minimal tissue toxicity. The major drawbacks of this irrigant are its caustic effect on periapical tissues and the potential to weaken dentin and reduce its flexural strength.(2)

Another widely used irrigating solution is Chlorhexidine (CHX) which has the property of substantivity and exceptional action against the canal flora. Now-a-days its use is reduced in endodontics as it causes unwanted discoloration of the tooth structure and its inability to dissolve the pulp.(3)

Inorganic or chemically manufactured irrigants have numerous harmful effects and safety issues. To overcome the harmful effects, herbal substitutes can be recommended (4) Literature has documented various plant extracts having antimicrobial and therapeutic properties which can serve the purpose of endodontic irrigation.(5) Vitex negundo Linn, a well-recognized plant in the field of Ayurveda, commonly known as Nirgundi which means to protect from all diseases. It has many beneficial actions like antibacterial, antiinflammatory, analgesic, antifungal, anti-histaminic and antioxidant.(6) Largest components of the Vitex negundo Linn. (Nirgundi) are glycosides, alkaloids and tannins. Previous studies have shown that the extracts of Vitex negundo Linn. (Nirgundi) leaf and bark possess 
strong antibacterial and antifungal property. Aqueous and alcoholic extracts of Vitex negundo Linn. have antibacterial effect against the bacteria that give positive and negative results in the gram stain test. Literature suggests that the use of the extracts of Vitex negundo Linn. may have the potential to be potent against E.faecalis.(7)

Keeping the background in mind, present study was planned to evaluate the relative effectiveness of Vitex negundo Linn. leaf extract as a root canal irrigant.

\section{Materials and Methods \\ Study design}

This in vitro study was conducted at Department of Pediatric and Preventive Dentistry, Sharad Pawar Dental College in collaboration with Vishakha Microbiology Laboratory, Nagpur; Department of Ras-Shastra and Bhaishajya Kalpana, Mahatma Gandhi Ayurveda College, Hospital and Research Centre, Salod (H) and Sophisticated Instrument Centre, Indian Institute of Technology, Indore. The study was reviewed and approved by the Institutional Ethics Committee.

\section{Method \\ Sample selection and segregation}

Forty Premolars were collected and cleaned with 5.25\% sodium hypochlorite for 1 hour after ultrasonic scaling. Care was taken that premolars which were included in the study had not been extracted prior to 3 months. Premolars were stored in $0.9 \%$ saline at 4 degree celsius until its use. Single rooted premolars extracted for orthodontic purposes were included in the study whereas carious or restored premolars with calcified canals and bifurcated canals were excluded.

After cleaning of the outer surface of premolars, decoronation was done using diamond disk. And the samples were standardized to a length of $14 \mathrm{~mm}$. Preparation of the canals was done using hand k-files of no.20 (Dentsply-Maillefer, Ballaigues, Switzerland), along with irrigation with saline. After the working length determination using RVG, the canals were instrumented. The outer surface of the roots of premolars was painted thrice with nail polish to inhibit bacterial invasion.

\section{Cultivation of Enterococcus faecalis and contamination of root canals}

Enterococcus faecalis cultured (ATCC 29212)

bacterial strain was stored at $4^{\circ} \mathrm{C}$. Streaking of plates containing BHI agar was done and incubated at $37^{\circ} \mathrm{C}$ for $24 \mathrm{hrs}$. The obtained colonies

were transported to $\mathrm{BHI}$ broth tubes and incubated further for 24 hours at $37^{\circ} \mathrm{C}$ to obtain a suspension of Enterococcus faecalis with McFarland 2 (6x $\left.10^{8} \mathrm{CFU} / \mathrm{mL}\right)$. Each root canal was inoculated with $10 \mu \mathrm{l}$ of the Enterococcus faecalis suspension using $1 \mathrm{ml}$ of sterile insulin syringe under the laminar air flow hood. A sterile 15 no $\mathrm{K}$ file was used to uniformly disperse the bacterial suspension till the working length for about 10 seconds.

\section{Collection of bacterial samples before instrumentation}

After 48 hours of incubation period, contaminated root canals were filled with fresh BHI broth. Samples were obtained by the sterile 20 no. paper points which were kept in the root canal for around 1 min, sterile tweezer was used for collecting the same. Absorbent paper points were removed and were moved into Eppendorf tubes containing $1 \mathrm{ml}$ BHI broth. Eppendorf tubes were then vortexed for 30 seconds to uniformly mix the contents of BHI broth. After 10 fold serial dilution, aliquots of $20 \mu \mathrm{l}$ were plated on sheep blood agar, and incubated at $37^{\circ} \mathrm{C}$ for 2 days. For every plate, the number of CFU were recorded.

\section{Root canal instrumentation}

Premolars used for the study were divided into four groups i.e. Sodium hypochlorite group, Chlorhexidine group, Vitex negundo Linn. group and Saline group respectively of 10 teeth each. Canal preparation was done upto size 35 no.K file. Rhodamine B fluorescent dye powder was quantitated to make $0.1 \mathrm{~m}$ mol/0.1\% Rhodamine B solution. Each irrigant $(2 \mathrm{ml})$ ( $\mathrm{NaOCl}, \mathrm{CHX}$, Vitex .negundo, saline) was used for irrigation respectively after instrumentation by each file. Irrigation of the root canal was done after instrumentation by each file, using 29 gauge needle and final irrigant volume used was $10 \mathrm{ml}$ per canal. Post instrumentation and irrigation again bacterial samples were taken using paper points and were cultured.

\section{Processing of Vitex negundo Linn. extract as irrigant (fig 1)}

Fresh leaves of Vitex negundo Linn. were collected from herbal garden of Mahatma Gandhi Ayurveda College, Hospital and Research Centre, Salod (H), Wardha.

Twenty gms of Vitex negundo Linn. leaves were collected and separated. The leaves were washed with water thoroughly and dried on a filter paper. Then the leaves were cut into thin sections and were grinded in a mortar with a pestle. The entire mixture was then tied in a muslin cloth and placed in thumble and the entire assembly was placed in soxhlet apparatus and mixture was extracted in $100 \mathrm{ml}$ ethanol by soxhlet apparatus at 40-50 degree Celsius. Filtered extract was kept in water bath for elimination of ethanol; $2.29 \mathrm{gm}$ extract was collected. The prepared extract was diluted in $10 \mathrm{ml}$ ethanol to obtain mother solution. Serial dilution method was used to obtain $100 \mathrm{mg} / \mathrm{ml}$ of solution and kept in refrigerator for further use.

Fig 1. Preparation of Vitex negundo Linn. extract as root canal irrigant

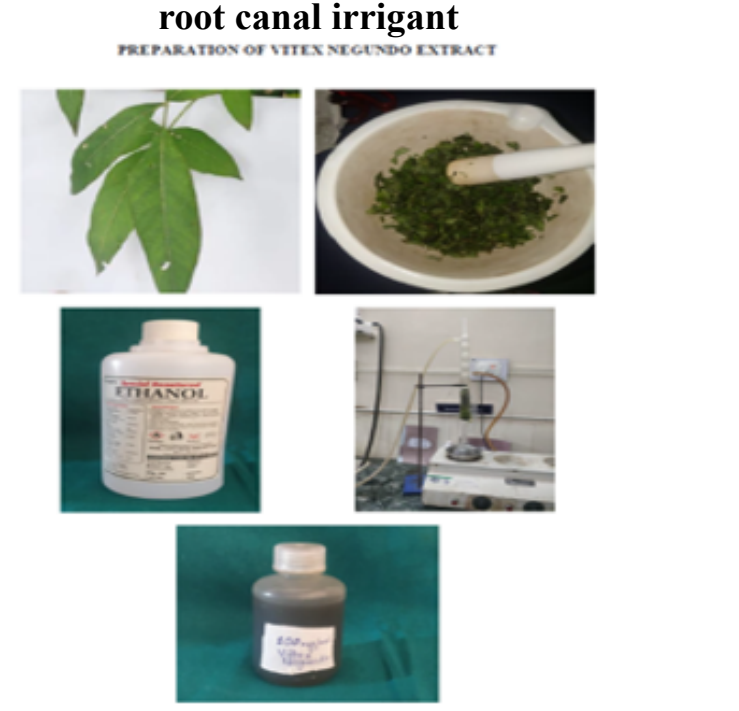




\section{Penetration depth of irrigants using CLSM}

Two markings were given at the level of the intersection of coronal and middle third and middle and apical thirds and were horizontally segmented using a diamond disc at $3 \mathrm{~mm}, 6 \mathrm{~mm}, 9 \mathrm{~mm}$ from the apex of the tooth. Each segment was standardized to a size of $1 \mathrm{~mm}$ and polished.

The root canal slices were visualised under confocal laser scanning microscope (Olympus, fluoview FV 1000 Japan) to evaluate irrigant penetration depth. For accurate visualization of all the images, sections were studied under 10X lens. Wavelength of $540 \mathrm{~nm}$ was used for absorption of rhodamine dye whereas $590 \mathrm{~nm}$ was used as emission wavelength. To measure the depth of penetration, the division of the images were done into 3 different regions. The final penetration depth was the derived mean out of the 3 readings. OLYMPUS FLUOVIEW Ver 4.2 viewer software was used for measuring the obtained images. Operator was blinded during assessment of all the samples of the groups. (fig 2)

Fig 2- Penetration depths of various irrigants at different levels in root dentin

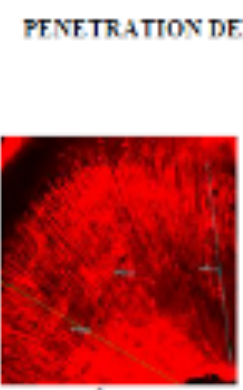

$9 \mathrm{man}$
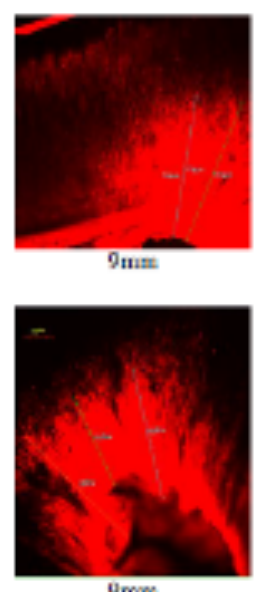

$9 \mathrm{~mm}$

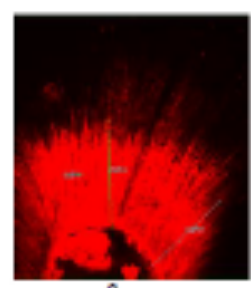

$9 \mathrm{~mm}$
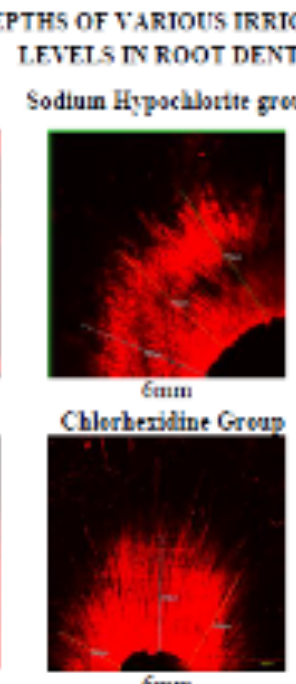

Emm

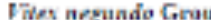

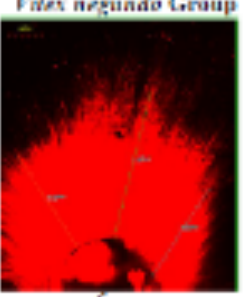

semm

Saline Gromp

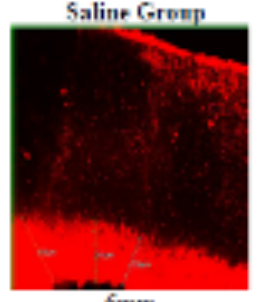

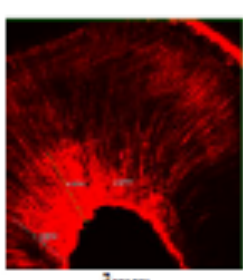

$3 \mathrm{~mm}$
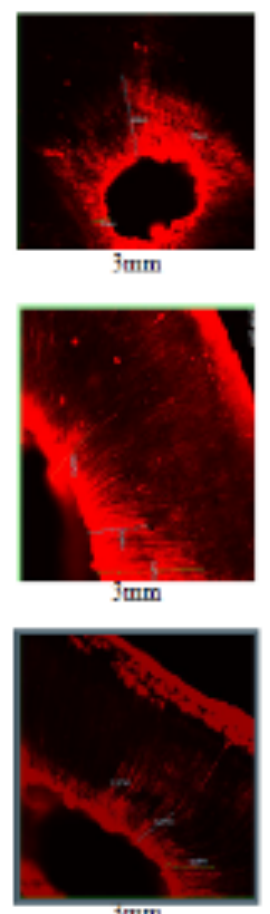

\section{Statistical Analysis}

Statistical analysis was carried out by descriptive and inferential statistics using Student's paired t-test, one way ANOVA and Post-hoc Tukey Test. Software used in the analysis was SPSS (Statistical Package for Social Sciences) Version 24.0 (IBM Corporation Chicago, USA) and GraphPad Prism 7.0 version. $\mathrm{p}<0.05$ was considered as level of significance.

\section{Observations and Results}

Graph 1: Comparison of all the groups for the mean $\mathrm{CFU} / \mathrm{ml}$ of Enterococcus faecalis before and after irrigation

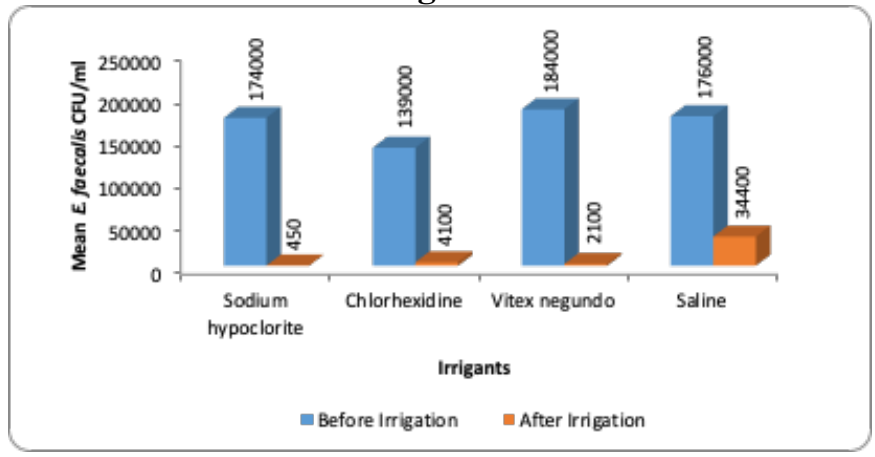

The mean reduction comparison of all the groups for the mean CFU/ml of Enterococcus faecalis before and after irrigation is shown in graph 1 . The mean CFU/ml of Enterococcus faecalis before irrigation were higher for Vitex negundo Linn. group (184000) followed in decreasing order for saline group (176000), sodium hypochlorite group (174000) and least values for CHX group (139000). After irrigation, CFU/ml values of Enterococcus faecalis showed the pattern in decreasing order as: Saline group (34400)> CHX group (4100) >Vitex negundo Linn. group (2100)> NaOCl group (450). Sodium hypochlorite group was found to show less $\mathrm{CFU} / \mathrm{ml}$ of Enterococcus faecalis post irrigation and has shown its efficiency to reduce Enterococcus faecalis levels significantly in comparison with all other groups of irrigants like CHX group, Vitex negundo Linn. group and Saline group.

\section{Graph 2: Summary of Comparison of Penetration Depth in all the groups at Coronal third, Middle third and Apical third levels}

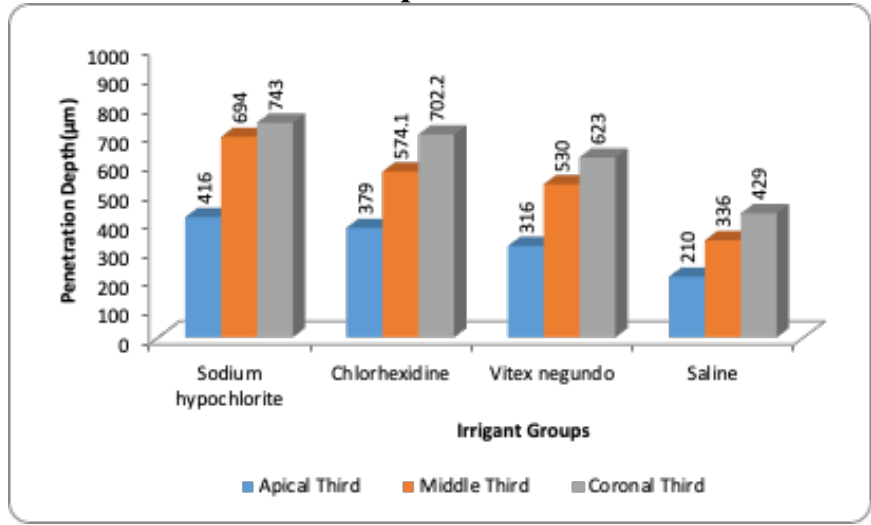


Graph 2 shows summary of comparison of penetration depth in all the groups at Coronal third, Middle third and Apical third levels. Penetration depth of irrigants at Coronal third level was highest with sodium hypochlorite group $(743 \mu \mathrm{m})$ followed by $\mathrm{CHX}$ group $(702.2 \mu \mathrm{m})$ followed by Vitex negundo Linn. (623 $\mu \mathrm{m})$ and least depth of penetration with saline group $(429 \mu \mathrm{m})$. Similarly, for middle third level maximum penetration depth scores obtained in sodium hypochlorite group $(694 \mu \mathrm{m})$ when compared with CHX group $(574.1 \mu \mathrm{m})$, Vitex negundo Linn. $(530 \mu \mathrm{m})$ and saline group $(336 \mu \mathrm{m})$. In the apical third level, values for penetration depth were again higher with sodium hypochlorite group $(416 \mu \mathrm{m})$ followed by $\mathrm{CHX}$ group $(379 \mu \mathrm{m})$, Vitex negundo Linn. group $(316 \mu \mathrm{m})$. Lesser values were obtained with saline group (210 $\mu \mathrm{m})$. Sodium hypochlorite group was found to show maximum penetration depth at all levels i.e. Coronal third, middle third and apical third levels, when compared with other group of irrigants like CHX group, Vitex negundo Linn. group and Saline group.

\section{Discussion}

Endodontic infection consists of a heterogeneous combination of microbial species.(8) Once the bacteria such as Streptococci, Veillonella parvula, Pepto streptococcus, Propioni bacterium, Lactobacilli, Eubacterium, Actinomyces, Bacteroides, Fusobacterium invade the pulpal tissue, the root canal becomes a "privileged sanctuary" for clusters of bacteria, their byproducts and degradation products of both pulpal tissue as well as bacterial microorganism.

The failed treatment has been attributed to the flora residing in the lateral canals, tubules of the dentin, ramifications and delta. These viable bacteria constantly act as a source of reinfection or continuous inflammation.(9) The microenvironment of root canal favors the selection of few bacterial species like Enterococcus faecalis, Streptococcus anginosus and Fusobacterium nucleatum.(10)Enterococcus faecalis was chosen for the present study as it is the most common bacteria associated with resistant or recurrent infections leading to endodontic treatment failure. $(11,12)$ Enterococcus faecalis is a non-fastidious, gram positive facultative anaerobe that can proficiently invade dentinal tubules, survive during chemomechanical instrumentation and intracanal medication, adjust to altered nutrient supply and continue to remain viable inside the dentinal tubules. Prevalence of Enterococcus faecalis ranges from $22 \%$ to $77 \%$ of cases.(13) One of the most potent virulence factors of the Enteroccoccus group that enhance the adaptation and also the survival in various environments are collagen binding protein (ace), Enterococcal surface proteins (esp) according to a variety of studies. $(10,14)$ They can tolerate an extensive range of growth conditions, including temperatures ranging from $10^{\circ} \mathrm{C}$ to $45^{\circ}$ C.(15) It has been suggested in studies that Enterococcus faecalis can resist various intracanal treatment procedures. $(15,16)$

Traditional use of mechanical instrumentation reduces the bacterial load from the canal by approximately 50\%. Thus, additional treatment modalities are required to assist in microorganism elimination from the inaccessible areas.(15) Ideally an irrigant should possess qualities such as: powerful antibacterial activity, dissolution of organic tissue remnants, root canal cleansing, expulsion of dentinal debris from canals post instrumentation and the periradicular tissue should be free of any cytotoxicity from the contents of the irrigant.(9) A large number of materials have been used for the disinfection of the root canals including normal saline, $\mathrm{NaOCl}, \mathrm{CHX}$, EDTA, HEBP, MTAD and newer materials like tetraclean and use of Ozone.(1)

$\mathrm{NaOCl}$ acts a potent antimicrobial agent and also has the ability to dissolve organic components of dentin such as the pulpal remnants and collagen. Several concentration of $\mathrm{NaOCl}$ ranging from $0.5 \%$ $6 \%$ have been used for root canal irrigation in various studies.(17-19). In the study conducted by Reyhani et $\mathrm{al}(20)$ it was observed that even lowest concentration i.e., $2.5 \% \mathrm{NaOCl}$ was able to denature endotoxins produced by bacteria and organic tissue dissolution. We used $3 \%$ concentration of $\mathrm{NaOCl}$ was therefore used as an intracanal irrigant.

The other widely used root canal irrigant in pediatric endodontics is Chlorhexidine (CHX). The antibacterial efficacy of $\mathrm{CHX}$ as a root canal irrigant is concentration dependent. Depending on its concentration, CHX can have both bacteriostatic and bactericidal effects. At high concentrations, whereas at low concentrations, $\mathrm{CHX}$ is bacteriostatic, It has been demonstrated that $2 \% \mathrm{CHX}$ has a better antibacterial efficacy than $0.12 \% \mathrm{CHX}$ in vitro. Therefore, it was decided to use $2 \% \mathrm{CHX}$ in the current study.(21) Although $\mathrm{NaOCl}$ and $\mathrm{CHX}$ have a wide spectrum of useful properties, they have certain disadvantages too.

Undesirable characteristics of $\mathrm{NaOCl}$ include its caustic nature, tissue damage risks if expressed under pressure into the periodontal ligament space and also reduction in flexural strength of dentin. $(3,21)$ Similarly, $\mathrm{CHX}$ when used as root canal irrigant, causes discoloration of the teeth, tongue and also dryness of the oral cavity.(3, 22-24) Hence, there is always a quest for an effective alternative root canal irrigant that fulfils the requirements of an ideal irrigant, with minimal possible side effects.

Literature has shown that certain natural plant extracts including various herbal extracts like Neem, Triphala, Aloe vera, Propolis, Green tea, Morinda citrifolia, Chamomile, Garlic extract etc. have antibacterial and medicinal effects, thus implicating their possibility to be used as an endodontic irrigant. (25) Vitex negundo Linn., commonly known as Nirgundi is a member of the Verbenaceae family, having a wide range of medicinal effects which are attributed to the metabolites like alkaloids, glycosides, tannins, flavonoids, steroids, carbohydrates.(7) Nirgundi has been previously used as a mouthwash in treatment of periodontal diseases and in relieving tooth pain.(26) It has also been incorporated in certain commercial products available in the market. Owing to the uses and properties like antibacterial, analgesic, antiviral, 
antifungal, anti-helminthic, anti-inflammatory, and immune-enhancing effects. (27)

Study performed by Deogade et al(27) 2016, in which various concentrations of Vitex negundo Linn. like $20 \mathrm{mg} / \mathrm{ml}, 40 \mathrm{mg} / \mathrm{ml}, 60 \mathrm{mg} / \mathrm{ml}, 80 \mathrm{mg} / \mathrm{ml}$ and $100 \mathrm{mg} / \mathrm{ml}$ had been used. The results of the study stated that $100 \mathrm{mg} / \mathrm{ml}$ of Vitex negundo Linn. plant extract exhibited maximum effectiveness against both Gram positive and Gram negative bacteria respectively. Therefore $100 \mathrm{mg} / \mathrm{ml}$ concentration of Vitex negundo Linn. was used in the present study. Numerous vehicles like ethanol, methanol, ether, ethyl acetate, chloroform and benzene had been used with Vitex negundo, but after comparison of solvents it was found that phenol and flavonoid contents were more in ethanolic extract. (28) Hence, in the present study, ethanolic extract of Vitex negundo Linn. was used.

Methodology employed in the present study was similar to that used by Nourzadeh et al(29) 2017, in which microbial reduction was assessed after chemomechanical debridement. In the same study, microbial samples were taken from the root canals with the use of absorbent paper points before and after chemomechanical debridement. Absorbent paper points were used for sample collection in the presentudy so as to obtain optimum growth of microbes.

Microbial count for Enterococcus faecalis in the form of colony forming units were recorded in the present study to assess the reduction in microbial growth pre and post irrigation. The mean $\mathrm{CFU} / \mathrm{ml}$ for Enterococcus faecalis before irrigation was $174000 \pm 12294$ which reduced to $450 \pm 263.52$ after $\mathrm{NaOCl}$ irrigation

After irrigation with $\mathrm{CHX}$, it was found in the present study that the mean $\mathrm{CFU} / \mathrm{ml}$ for Enterococcus faecalis before irrigation were $139000 \pm 44833.02$ which reduced to $4100 \pm 2330.95$ post-irrigation. In the present study, mean CFU/ml for Enterococcus faecalis in Vitex negundo Linn. group before irrigation were $18400 \pm 120296$ which reduced to $2100 \pm 1173$ post irrigation. Sibaram et al(7) (2011)and Kekuda et al(30) (2014) stated that significant antibacterial activity of Vitex negundo Linn. against $E$. faecalis. Studies done by Renisheya et al(31) (2011) and Dubey and Padhy(32) (2012) showed that ethanolic extracts of Vitex negundo Linn. inhibited microorganisms like $S$. aureus and Enterococcus faecalis respectively. Comparable antibacterial activity was found in the present study. Saline group showed significant reduction in bacterial count from $176000 \pm 121765$ to $34400 \pm 22741.05$ post irrigation.

All the groups i.e. $\mathrm{NaOCl}, \mathrm{CHX}$ and Vitex negundo Linn. showed significant reduction in bacterial count in intergroup comparision and intragroup comparsion. These results obtained are similar to study carried out by Chandwani et al(5) (2017), where they found that when antimicrobial activity of $\mathrm{NaOCl}$ and Morinda citrifolia juice as an irrigant was compared, $\mathrm{NaOCl}$ was found to show similar results as that of Morinda citrifolia juice in terms of reducing mean $\mathrm{CFU} / \mathrm{ml}$ for $E$. faecalis. Babaji et al(33) (2016), reported that MCJ, Neem and Aloe vera extracts when used as root canal irrigants against $\mathrm{NaOCl}$ showed lesser antibacterial activity against Enterococcus faecalis in terms of inhibition zones in the increasing order of Aloe vera $<\mathrm{Neem}<\mathrm{MCJ}<\mathrm{NaOCl}$. All the root canal irrigants in the present study were able to show significant bacterial reduction and the effectiveness observed ranged in decreasing order as $\mathrm{NaOCl}>\mathrm{CHX}>$ Vitex negundo $>$ Saline.

Taking into consideration the ideal requirements of the root canal irrigating solutions, it is said that for root canal irrigants, antimicrobial activity is not only important but at the same time it is equally important that it should kill the deeply penetrated bacteria within the dentinal tubules.(9)Enterococcus faecalis has been observed to have penetrated up to $1000 \mu \mathrm{m} .(34,35)$

For evaluation of penetration depth of root canal irrigants, several methods like Dye bleaching, Radiographic visualization, SEM, Gates Glidden drills and CLSM have been employed by various authors as found in literature.(29,36-38) However, amongst all these methods, CLSM has the advantages like ease in sample processing and preparation which tends to produce smaller number of artefacts. $(39,40)$ Therefore, the method using Confocal Laser Scanning Microscopy was chosen. Rhodamine B dye was used to visualize the penetration using CLSM because of its smaller particle size and increased infusibility in dentinal tubules and easy visualization.(41)

The results of the study revealed that the average penetration depth of $3 \% \mathrm{NaOCl}$ in coronal third level was $743 \mu \mathrm{m}$ at $9 \mathrm{~mm}$ followed by $694 \mu \mathrm{m}$ at $6 \mathrm{~mm}$ in the mid-level and $416 \mu \mathrm{m}$ at $3 \mathrm{~mm}$ in the apical third level. The mean penetration depth of $2 \% \mathrm{CHX}$ in the $\mathrm{t}$ study at coronal, middle and apical third levels were $702 \mu \mathrm{m}, 574 \mu \mathrm{m}$ and $372 \mu \mathrm{m}$ respectively.. Similar pattern of effectiveness was observed in study done by Vandana et al(40) 2015 in which penetration depth of CHX as irrigant using conventional irrigation method was $138 \mu \mathrm{m}, 80 \mu \mathrm{m}$ and $44 \mu \mathrm{m}$ at coronal third, middle third and apical third levels respectively. These results differ in values at all levels when compared to our study. This difference in value could be because of difference in types of teeth used and difference in distance for recording the penetration depth.

Current study shows that the mean penetration depth at $9 \mathrm{~mm}, 6 \mathrm{~mm}$ and $3 \mathrm{~mm}$ for Vitex group was 623 $\mu \mathrm{m}, 530 \mu \mathrm{m}$ and $316 \mu \mathrm{m}$ and for saline was $429 \mu \mathrm{m}$, $336 \mu \mathrm{m}$ and $210 \mu \mathrm{m}$ respectively. Increased penetration was seen in all the groups at the coronal third and middle third portion and least amount was seen in apical one third of root canals which shows similarity in pattern of effectiveness seen in studies done by Llena et al(39) and Vandana et al(40). Their studies showed that the irrigant penetration in the apical most region was the lowest. Reason quoted for the same are: the number of patent dentinal tubules are reduced due to presence of sclerotic dentin in apical region and increased amount of peritubular dentin is also seen. $(39,40)$ Also the anatomy of apical region makes it difficult for irrigants to access and remove the smear layer and debris. These might be some of the causative factors for limited 
penetration in the portion near apex. Higher penetration seen in coronal third and middle third levels in the present study could be because of the larger tubular size of the dentin in the coronal part of the canal and the absence of complex anatomical structures.(42) Dentinal tubules hoard the maximum bacteria and thus must be cleaned effectively and efficiently. (43)

In the present study, all the four root canal irrigants, $\mathrm{NaOCl}, \mathrm{CHX}$, Vitex negundo Linn. and saline showed satisfactory antibacterial activity against Enterococcus faecalis as well as penetration depth in dentinal tubules. Comparative order of efficacy of root canal irrigants in decreasing order for both parameters observed was $\mathrm{NaOCl}>\mathrm{CHX}>$ Vitex negundo $>$ Saline.

Owing to the antimicrobial, analgesic, antifungal and anti-inflammatory properties shown by Vitex negundo, present study attempted to use Vitex negundo Linn. which was found to be successful in showing its effectiveness in terms of its antibacterial effect and penetration ability in dentin.(27) Herbal extracts like Vitex negundo Linn. prove to be potential alternatives to commonly available irrigants for root canals of primary teeth and can be used in day to day practice with minimal side effects. Herbal extracts thus must be used in order to reduce potential side effects from occurring and for enhanced antibacterial properties and to overcome resistance to conventional irrigants. $(44,45)$.

\section{References}

1. Kandaswamy D, Venkateshbabu N. Root canal irrigants. J Conserv Dent. 2010;13(4):256-264.

2. Gomes BP, Ferraz CC, Vianna ME, Berber VB, Teixeira FB, Souza-Filho FJ, et al. In vitro antimicrobial activity of several concentrations of sodium hypochlorite and chlorhexidine gluconate in the elimination of Enterococcus faecalis. Int Endod J. 2001;34:424-428.

3. Alharbi A, Aliuddin S, Alharbi TA, Alharbi S, Alanzi AO, Alharbi AA, et al. Herbal Endodontic Irrigants. Int $J$ Prev Clin Dent Res. 2017;4(4):311-314.

4. Pujar M, Makandar S. Herbal usage in endodonticsa review. Int J Contemp Dent. 2011 Jan;2(1):34-37.

5. Chandwani M, Mittal R, Chandak S, Pimpale J. Effectiveness of Morinda citrifolia juice as an intracanal irrigant in deciduous molars: An in vivo study. Dent Res J (Isfahan). 2017;14(4):246-251.

6. Gill BS, Mehra R, Navgeet and Kumar S. Vitex negundo Linn. and its medicinal value. Mol Biol Rep.2018;45(6), 2925-2934.

7. Paria S, Chaki S, Ghosdastidar S, Mookerjee M. Evaluation of antimicrobial activity and antioxidant property of $\mathrm{V}$. Negundo Leaf Extract. IJDFR. 2011;2(4):337-45.

8. Rana V, Baba SM, Pandey A. Bacteriology of infected deciduous root canal: A review. People's Journal of Scientific Research. 2009;2(2):45-8.

9. Rajeshwari, Premanand K, Kundabala M, Shenoy S, Hegde V, Thukral N. An evaluation of horizontal depth of penetration of various irrigants into the dentinal tubules when used alone and in combination with diode laser: An in vitro study. Journal of Interdisciplinary Dentistry. 2014; 4(3): 130

10. Preethee T, Kandaswamy D, Arathi G, Hannah R. Bactericidal effect of the $908 \mathrm{~nm}$ diode laser on Enterococcus faecalis in infected root canals. J Conserv Dent. 2012;15(1):46-50.

11. Shailaja S, Suresh BS, Endodontic Microflora- A Review, J Oral Health Comm Dent. 2014;8(3):160-165.

12. Sohrabi K, Sooratgar A, Zolfagharnasab K, Kharazifard MJ, Afkhami F. Antibacterial Activity of Diode Laser and Sodium Hypochlorite in Enterococcus Faecalis-Contaminated Root Canals. Iran Endod J. 2016;11(1):8-12.

13. Asnaashari M, Safavi N. Disinfection of Contaminated Canals by Different Laser Wavelengths, while Performing Root Canal Therapy. J Lasers Med Sci. 2013;4(1):8-16.

14. Giard JC, Hartke A, Flahaut S, Benachour A, Boutibonnes P, Auffray Y. Starvation- induced multiresistance in Enterococcus faecalis $\mathrm{JH} 2-2$. Curr Microbiol. 1996;32(5):264-71.

15. Saber Sel D, El-Hady SA. Development of an intracanal mature Enterococcus faecalis biofilm and its susceptibility to some antimicrobial intracanal medications: An in vitro study. Eur J Dent. 2012;6(1):43-50.

16. Vatkar NA, Hegde V, Sathe S. Vitality of Enterococcus faecalis inside dentinal tubules after five root canal disinfection methods. J Conserv Dent. 2016;19(5):445- 449.

17. Estrela C, Ribeiro RG, Estrela CR, Pécora JD, Sousa-Neto MD. Antimicrobial effect of $2 \%$ sodium hypochlorite and $2 \%$ chlorhexidine tested by different methods. Brazil Dent J. 2003;14(1):58-62.

18. Vianna ME, Gomes BP, Berber VB, Zaia AA, Ferraz CC, de Souza-Filho FJ. In vitro evaluation of the antimicrobial activity of chlorhexidine and sodium hypochlorite. Oral Surg Oral Med Oral Pathol Oral Radiol Endod. 2004;97:79-84.

19. Dutner J, Mines P, Anderson A. Irrigation trends among American association and endodontists members: A web-based survey. J Endod. 2012;38:37-40.

20. Reyhani M, Ghasemi N, Soroush-Barhaghi M, Amini M, and Gholizadeh Y. Antimicrobial efficacy of different concentration of sodium hypochlorite on the biofilm of Enterococcus faecalis at diferent stages of development. Journal of Clinical and Experimental Dentistry. 2016;8(5):480-484.

21. Basrani B, Tjäderhane L, Santos JM, Pascon E, Grad H, Lawrence HP, Friedman S. Efficacy of chlorhexidine and calcium hydroxide-containing medicaments against enterococcus faecalis in vitro. Oral Surg Ora Med Oral Pathol Oral Radiol Endod. 2003;96:618-24.

22. Sharma A, Chopra H. Chlorhexidine urticaria: a rare occurrence with a common mouthwash. Indian J Dent Res. 2009;20(3):377-379. 
23. Mohammadi Z. Chlorhexidine gluconate, its properties and applications in endodontics. Iran Endod J. 2008.;2(4):113-125.

24. Badole GP, Bahadure RN, Kubde R. Herbal medicines in endodontics: an overview. J Dent Oral Disord. December 2016 ;2(9):1046.

25. Jain $P$, Ranjan $M$. Role of herbs in root canal irrigation-A review. Journal of Pharmacy and Biological Sciences. 2014;9(2):06-10

26. Ahuja SC, Ahuja S, Ahuja U. Nirgundi (Vitex negundo) - Nature's Gift to Mankind. Asian AgriHistory. 2015;19(1):5-32.

27. Deogade M, Pandya T, Kethamakka, Prasad S, Kale K, Tankhiwale N.Antimicrobial Activity of Vitex negundo Linn. Linn. (Nirgundi) Leaves Extract. J. Res. Trad. Medicine. 2016;2(4):99-102

28. Raghavendra HL, Vijayananda BN, Madhumathi HG, Kumar V. In vitro antioxidant activity of Vitex negundo Linn. L. Leaf extracts. Chaing Mai J Sci. 2010;37:489-97.

29. Nourzadeh M, Amini A, Fakoor F, Raoof M, Sharififar F. Comparative Antimicrobial Efficacy of Eucalyptus Galbie and Myrtus Communis L. Extracts, Chlorhexidine and Sodium hypochlorite against Enterococcus Faecalis. Iran Endod J. 2017;12(2):205-210.

30. Prashith KTR, Vivek MN, Yashoda K, Manasa M , Rekha C, Raghavendra HL. Comparative Study on Antimicrobial activity of Vitex negundo Linn. Var. Negundo and Vitex negundo Linn. Var. Purpurascens. Sci. Technol. Arts Res. J. 2014;3(1): 126-131.

31. Renisheya JJMT, Johnson M, Mary Uthith M, and Arthy A. Antibacterial activity of ethanolic extracts of selected medicinal plants against human pathogens, Asian Pacific Journal of Tropical Biomedicine. 2011; 1(1):S76-S78

32. Dubey D, Padhy RN. Surveillance of multidrug resistance of two Gram-positive pathogenic bacteria in a teaching hospital and in vitro efficacy of 30 ethnomedicinal plants used by an aborigine of India. Asian Pacific Journal of Tropical Disease. 2012;2(4): 273-281.

33. Asnaashari M, Safavi N. Disinfection of Contaminated Canals by Different Laser Wavelengths, while Performing Root Canal Therapy. J Lasers Med Sci. 2013;4(1):8-16.

34. Haapasalo M, Orstavik D. In vitro infection and disinfection of dentinal tubules. J Dent Res. 1987;66:1375-1379.
35. Al-Nazhan S, Al-Sulaiman A, Al-Rasheed F, Alnajjar F, Al-Abdulwahab B, Al- Badah A. Microorganism penetration in dentinal tubules of instrumented and retreated root canal walls. Restorative Dentistry \& Endodontics. 2014;39(2):258-264.

36. Mamootil K, Messer HH. Penetration of dentinal tubules by endodontic sealer cements in extracted teeth and in vivo. Int Endod J. 2007;40:873-881.

37. Zou L, Shen Y, Li W, Haapasalo M. Penetration of sodium hypochlorite into dentin. Journal of Endodontics. 2010;36:793-796.

38. Dhaimy S, Imdary S, Dhoum S, Benkiran I, El Ouazzani A. Radiological Evaluation of Penetration of the Irrigant according to Three Endodontic Irrigation Techniques. Int J Dent. 2016;2016:1-6.

39. Llena C, Forner L, Cambralla R, Lozano A. Effect of three different irrigation solutions applied by passive ultrasonic irrigation. Restor Dent Endod. 2015;40:143-148.

40. Vadhana S, Latha J, Velmurugan N. Evaluation of penetration depth of $2 \%$ chlorhexidine digluconate into root dentinal tubules using confocal laser scanning microscope. Restor Dent Endod. 2015;40(2):149-154.

41. Azoubel E, Veeck EB. Análise do vedamento apical em dentes monorradiculares submetidos à obturação retrógradae irradiação com laser Nd:Yag. Rev Fac Odontol Univ Fed Bahia. 1998;17:25-35.

42. Rajakumaran A, Ganesh A. Comparative Evaluation of Depth of Penetration of Root Canal Irrigant After Using Manual, Passive Ultrasonic, and Diode Laser- Assisted Irrigant Activation Technique. $J$ Pharm Bioallied Sci. 2019;11(2):216- 220.

43. Tiwari S, Nikhade P, Chandak M, Sudarshan C, Shetty P, Gupta NK. Impact of Various Irrigating Agents on Root Fracture: An in vitro Study. J Contemp Dent Pract 2016;17(8):659-662.

44. Chandak, M.G., R.R. Modi, B.J.J. Rathi, R.J. Gogiya, and P. Bhutada. "In Vitro Comparative Assessment of Diffusion of Ion from Calcium Hydroxide with Three Different Phytomedicine Pastes through Dentin." World Journal of Dentistry 9, no. 5 (2018): 366-71. https://doi.org/10.5005/jpjournals-10015-1564.

45. Das, A., M. Chandak, and S. Kela. "Comparative Evaluation of Antifungal Efficacy of Two Endodontic Irrigation on Candida Albicans: An inVitro Study." Journal of Datta Meghe Institute of Medical Sciences University 10, no. 4 (2015): 22022. 